\begin{tabular}{|c|l|}
\hline Title & Effects of sedge and cottongrass tussocks on plant establishment patterns in a post-mined peatland, northern Japan \\
\hline Author(s) & Koyama, A suka; Tsuyuzaki, Shiro \\
\hline Citation & $\begin{array}{l}\text { Wetlands Ecology and Management, 18(2), 135-148 } \\
\text { https:/doi.org/10.1007/311273-009-9154-6 }\end{array}$ \\
\hline Issue Date & 2010-04 \\
\hline Doc URL & http://hdl.handle.net/2115/49206 \\
\hline Rights & The final publication is available at www.springerlink.com \\
\hline Type & article (author version) \\
\hline File Information & WEM18_2_135-148.pdf \\
\hline
\end{tabular}

Instructions for use 


\title{
Effects of sedge and cottongrass tussocks on plant establishment patterns in a post-mined peatland, northern Japan
}

\author{
Asuka Koyama $^{1}$, Shiro Tsuyuzaki ${ }^{2}$ \\ ${ }^{1}$ Graduate School of Environmental Science, Hokkaido University, Sapporo, 060-0810, Japan \\ ${ }^{2}$ Graduate School of Environmental Earth Science, Hokkaido University, Sapporo, 060-0810, \\ Japan
}

Corresponding address: akoyama@ees.hokudai.ac.jp

Asuka Koyama

Address:

Graduate School of Environmental Science, Hokkaido University, Sapporo, 060-0810, Japan

Phone: +81.11 .706 .2264$

Fax: +81.11 .706 .4954$

email: akoyama@ees.hokudai.ac.jp 
Keywords facilitation, life-history stage, litter, microhabitat, post-mined peatland, tussock

\begin{abstract}
Facilitation (positive inter-specific interaction) plays an important role in promoting succession in harsh environments. To examine whether tussocks facilitate the establishment of other species, after peat mining, investigations were carried out in a formerly Sphagnum-dominated wetland (Sarobetsu mire, northern Japan). Two tussock-forming species, Carex middendorffii and Eriophorum vaginatum, have established in sparsely vegetated areas, with a dry ground surface, since peat extraction ended. The following factors were examined, in three microhabitats created by tussocks $($ center $=$ raised tussock center, edge $=$ tussock edge covered with litter, and flat = flat areas without tussocks): (1) relationships between tussock microhabitats and plant distributions, and (2) the effects of tussocks on survival, growth, flowering and seed immigration of common species. Two $(1 \times 10 \mathrm{~m})$ plots were established, in each of three sparsely vegetated sites, in September 2005. Tussocks were mapped in each plot, and species, location, flowering, growth stage (seedling, juvenile and fertile) and size of all plants were recorded, during snow-free periods from September 2005 to September 2006. Seed traps were used to investigate seed dispersal from June to October 2006. Four native species, Drosera rotundifolia, Lobelia sessilifolia, Moliniopsis japonica, Solidago virgaurea, and an exotic species, Hypochaeris radicata, were most common. During seedling and juvenile stages, these species were distributed more densely at the tussock edge than in the flat areas, but were less common at the center. $H$. radicata had a higher survival rate at the edge than in the flat during the winter. The annual growth of $H$. radicata, L. sessilifolia and S. virgaurea was higher at the edge. Seed traps detected that $D$. rotundifolia seeds accumulate more at the edge. In conclusion, tussocks facilitated plant establishment in the edge microhabitat by providing litter cover, enhancing seed accumulation, germination and survival, and thus promoted revegetation. However, Sphagnum mosses have not established in the study sites, and the vegetation differs strongly from the areas where no peat mining had taken place.
\end{abstract}




\section{Introduction}

Peat mining has been extensively conducted for commercial use, such as soil improvement and gardening, in boreal peatlands, e.g., Canada (Lavoie et al. 2005), northern Europe (Tuittila et al. 2000), and northern Japan (Nishimura et al. 2009), and completely removes vegetation and seedbank. Lacking plant cover and litter, the post-mined ground surface becomes harsh by exposure to high solar radiation and strong winds (Campbell et al. 2002). Facilitation (positive inter-specific interaction) may have an important role in revegetation after peat mining (Bertness and Callaway 1994; Callaway and Walker 1997).

Wetland tussocks consist of various monocotyledonous species in genera Carex, Juncus, Eriophorum and Triglochin, etc. (Fogel et al. 2004; Crain and Bertness 2005; Ervin 2005). The microtopography created by tussocks affects the establishment of other plant species. However, the effects of tussocks differ between species and between habitats. Triglochin maritimum facilitates seedling establishment by raised microtopography that ameliorates waterlogging and salinity stresses in salt marsh (Fogel et al. 2004). The raised center of Carex nudata tussocks provides stable substrates for plant survival, by escaping floods in winter beside streams (Levine 2000). In post-mined peatlands, Eriophorum vaginatum tussocks facilitate plant establishment around tussocks by providing a humid microclimate (Tuittila et al. 2000) and by increasing peat surface stability (Campbell et al. 2002).

Litter accumulation alters physical environments such as light, soil temperature, soil humidity (Facelli and Pickett 1991; Bosy and Reader 1995; Eckstein and Donath 2005), and affects seed germination and seedling establishment (Bosy and Reader 1995; Xiong and Nilsson 1999). The effects of live shoots on seed germination and seedling survival are different from dead shoots (litter) (Morris and Wood 1989; Bergelson 1990). The area around tussocks, i.e., the edge, is occupied by litter, while tussock centers consist of live and dead shoots. Therefore, the function of the edge should be different from the center, for plant establishment.

Facilitation affects various plant life-history stages: seed dispersal, seedling emergence, 
survival, growth and reproduction (Chapin et al. 1994; Callaway and Walker 1997; Walker et al. 2003). For example, Buxus sempervirens shrub patches facilitate the seed germination of Quercus humils by improving microclimate in calcareous grasslands, but inhibit the seedling growth by shading (Rousset and Lepart 2000). Therefore, the effects of tussocks on plant establishment should be evaluated throughout all life-history stages.

Cushion plants sometimes facilitate the invasion, of not only natives but also exotics, by amelioration of physical stress (Crooks 2002; Cavieres et al. 2008). A cushion plant, Azorella monantha, facilitates seedling survival of two exotic species, Taraxacum officinale and Cerastium arvense, in the Andes (Badano et al. 2007). In addition, invasion of exotic species has been reported in peatlands fragmented by anthropogenic activities (Pellerin and Lavoie 2000). Tussocks may facilitate the establishment of exotic species more than native species in post-mined peatlands.

Sarobetsu mire is located in northern Japan, and the peat layer is up to $6 \mathrm{~m}$ deep (Hotes et al. 2006). Peat mining was conducted at more than $3 \mathrm{~m}$ depth, by a large suction-type peat-rig from 1970 to 2003 (Nishimura et al. 2009). Peat residue that was discarded on the original post-mined site, floated up on the water surface created by mining. This residue created a peat ground surface, although this process took over 10 years. Nowadays, the entire ground surface is firmly packed with the thick peat residues. On the peat ground surface, two tussock-forming species, Carex middendorffii Fr. Schm. and Eriophorum vaginatum L., established in sparsely vegetated areas. We evaluated the effects of three microhabitats; tussock center, tussock edge, flat without tussock, on plant establishment by addressing the following two questions: 1) Do tussock microhabitats promote plant establishment on natives and/or exotics? 2) How do tussocks promote the establishment, via life-history stages (seed immigration, survival, growth and flowering), of native and exotic species?

\section{Methods}


Study site

Sarobetsu mire $\left(45^{\circ} 06^{\prime} \mathrm{N}, 141^{\circ} 42^{\prime} \mathrm{E}, 7 \mathrm{~m}\right.$ a.s.l.) is located in the northernmost part of Hokkaido Island, northern Japan. In 2006 when the bulk of the monitoring was conducted, annual precipitation was $1163 \mathrm{~mm}$ at Toyotomi Town, $6 \mathrm{~km}$ east of the study site (SDMO 2006). The mean annual temperature was $6.6^{\circ} \mathrm{C}$ with a mean monthly minimum of $-6.9^{\circ} \mathrm{C}$ in January and a mean monthly maximum of $21.7^{\circ} \mathrm{C}$ in August. Maximum wind velocity during the seed dispersal period from June to October, indicated below storm force winds, i.e., less than $7 \mathrm{~m} / \mathrm{s}$. Easterly wind predominated during June, July and August, while northwesterly wind was frequent in September and October. Snow cover usually remains from November to April, and frost occurs even at the beginning of summer (Yamada and Takahashi 2004).

The original vegetation, where peat mining has not been conducted, is dominated by Sphagnum papillosum and S. magellanicum with C. middendorffii, Moliniopsis japonica and Andromeda polifolia (Nishimura et al. 2009), and has few tussocks. In a post-mined peatland where plots were established, thirty-three years have passed since the 17.1-ha area of peat was mined, in 1972. Although seeds could immigrate to the post-mined areas from the surrounding original Sphagnum mire 500-800 $\mathrm{m}$ far away from the plots, the amount of immigrated seeds is considered to be small (Egawa et al., in press). Sphagnum spp. did not establish in the surveyed plots. Grasses and sedges, such as Phragmites australis W. Clayton, Moliniopsis japonica Hayata and Rhynchospora alba Vahl., develop well in the post-mined area (Nishimura et al. 2009). Tussocks are common in sparsely vegetated post-mined areas, and are distributed patchily. Three sites with well-developed tussocks were chosen for this study, and were 100-300 m apart from each other. Two $1 \times 10 \mathrm{~m}$ plots were established by September 2005 in each site where $P$. australis was less abundant, to eliminate the shading effects of $P$. australis that often exceeded tussock height. The six plots were coded A to F.

Tussock distribution and measurements of tussock-sizes 
Tussocks in plots, and less than $1 \mathrm{~m}$ from plot margins, had the following information recorded; species, coordinates, diameters of the center and base, and height, this was done in 2005 (Fig. 1). Only tussocks more than $5 \mathrm{~cm}$ high were measured. The number of flowering culms on each tussock was counted in 2006. Microhabitats were classified into three categories (center, edge and flat) based on biotic microenvironments created by the shoots and litter of tussocks. 'Center' is a raised area on the tussock where shoots and litter are established. 'Edge' means the marginal area of the center that is covered with litter made of tussock shoots and is ring shaped. Litter was mostly connected with tussocks, and overlay the center and edge. The width of the edge varied, but was less than $20 \mathrm{~cm}$, depending on tussock size and shoot length. 'Flat' means the areas without tussocks and their litter. The area of each microhabitat was calculated from overhead-view maps, and thus edge area was underestimated because of the slope gradient.

Plant distribution, survival, growth and flowering

On each aboveground shoot in the plots, species, coordinates, basal area including rosettes (if available long and short axes) and growth stage were recorded in September 2005, and were monitored monthly from May to late September in 2006. An aboveground shoot was equivalent to an individual in most cases, except when closely aggregated shoots were developed. When $R$. alba developed a dense turf, measurements of cover of $R$. alba were done by ruler. Polytrichum spp. established on a few tussocks with low cover, and were not recorded. The maximum plant size, during 2006, was used for growth analysis. Growth stages were classified into three categories: seedling (emerged in 2006), fertile (producing flowers), and juvenile (between seedling and fertile stages). Preliminary observations showed that all flowering individuals surviving for two years from 2005 to 2006, produced flowers in both the years. Therefore, the possibility that the juvenile stage included senescent non-flowering individuals 
was low. The common species in the plots were Drosera rotundifolia L., Hypochaeris radicata L., Lobelia sessilifolia Lamb., M. japonica and Solidago virgaurea L. var. leiocarpa Benth, and were applied to all statistical analyses. H. radicata is exotic, and the other species are native.

Seed dispersal patterns

To estimate seed dispersal in each microhabitat, seed traps were constructed from plastic Petri dishes (8.8 cm in diameter) lacquered with sticky grease (Jefferson and Usher 1989; Chabrerie and Alard 2005) and were set up on and around 24 tussocks adjacent to the 6 plots, these seed traps were monitored from June 13 to October 23 2006, at 7-to 12-day intervals. The traps were replaced at every census to maintain high seed recovery. Two $C$. middendorffii and two $E$. vaginatum tussocks were selected for setting seed traps near each plot, the size of these tussocks ranged from $12 \mathrm{~cm}$ to $24 \mathrm{~cm}$ in height, to eliminate size effects on seed dispersal. Within one meter from the tussocks there were no obstacles, including other tussocks. Eleven seed traps were established in and around each tussock, i.e., one trap at the center, six at the edge, and four 20-60 cm away from the edge, in four cardinal directions. Thirty traps were additionally set up on flat ground more than $1 \mathrm{~m}$ away from any tussocks.

Water depth and microenvironment between habitats

Groundwater level was measured, more than three days after rainfall, every month from late April to October 2006, using three vinyl chloride pipes inserted near each plot. Volumetric water content down to $12 \mathrm{~cm}$ deep, from the ground surface, was measured by a time domain reflectometry (TDR) (Hydrosense, Campbell Scientific, Logan, USA) with a 12-cm probe, in each month from May to September 2006. The values were calibrated by peat samples collected from the study site (Paquet et al. 1993). Water content was measured at six points, along each of four sectional lines, of which the midpoints were located on tussock center, 
mounded east-west, i.e., at center, edge ( 0 and $10 \mathrm{~cm}$ from the base of a tussock), and flat (20, 40 and $80 \mathrm{~cm}$ ). Light intensity was measured by temperature/light data loggers (HOBO, UA-002-64, Onset Computer, Bourne, USA) set up on the ground surface, at the center and east edge in each of $C$. middendorffii and E. vaginatum tussocks, and flat at 1-hour intervals from May to September 2007. The data were calibrated to photosynthetically active radiation (PAR) by comparison to a PAR sensor (HOBO, S-LIA-M003, Onset Computer) established in an open area. A logger at the edge of $C$. middendorffii tussock did not record data. Temperature below $5 \mathrm{~cm}$ deep was measured by automatic thermometers (StowAway Tidbit TBI32-20+50, Onset Computer) at 1-hour intervals from June to October 2006. Three thermometers were set up at the center, edge, on the west and east sides of each tussock, and also on the flat. The data collected on the west and east sides of the edge were averaged and used for analysis.

Statistical analysis

To evaluate the microhabitat preferences of five common species, with three growth stages, a generalized linear model (GLM) was used with Poisson distribution and a logistic link. On each growth stage, microhabitat in each plot was used as an explanatory variable, with the offset of the differences in three microhabitat areas, and number of individuals on each microhabitat in each plot in 2006, was used as a response variable. Determinants on survivals from September 2005 to May 2006, and from May to September 2006, and flowering in 2006 were compared between microhabitats, with a consideration of plant sizes, using a generalized linear mixed model (GLMM) with a binomial distribution and a logit link. Growth of common species from September 2005 to August 2006 was compared between microhabitats by GLM, with a negative binomial distribution and a logistic link. The plant sizes in September 2005 and microhabitats were used as responsible variables and the maximum plant size in 2006 was an explanatory variable. Plant sizes in September 2005 were log-transformed before use. To investigate whether the effects of tussocks on plant establishment were different between two 
tussock-forming species, two models were developed and compared. Akaike's Information Criteria (AIC) was used to select which model was better (Burnham and Anderson 2002). The model used tussock-forming species as two categorical explanatory variables. Another model merged two tussock-forming species into a variable. When the former model was selected, the difference of tussock-forming species was significant. The models were applied to microhabitats in which number of individuals was more than 10 .

To evaluate relationships between microhabitat and seed immigration on each species, three models were explored by GLM with negative binomial distribution and a logistic link. Model 1 assumed that seed immigration was even everywhere. Model 2 assumed that seed immigration was different between flat and other two microhabitats, center and edge. Model 3 assumed that the amount of seed immigration was different between the three microhabitats. The best-fit models were selected by AIC.

Differences in volumetric water content in peat were compared between microhabitats, using repeated-measures ANOVA after arcsine transformation. All statistical analyses were conducted with the statistical program R (ver. 2.6.1) (R Development Core Team 2007).

\section{Results}

Distribution of tussocks and common species

In and around the six plots, 53 C. middendorffii and 81 E. vaginatum tussocks were recorded (Fig. 1). More than $70 \%$ of the tussocks produced flowering culms, showing that the tussocks had reached mature stages. C. middendorffii and E. vaginatum tussocks did not differ greatly in size. The basal area of $C$. middendorffii tussocks was $685 \pm 650 \mathrm{~cm}^{2}$ (mean $\pm \mathrm{SD}$ ) and the height was $14 \pm 6 \mathrm{~cm}$, compared to those of E. vaginatum, $809 \pm 584 \mathrm{~cm}^{2}$ (basal area) and $14 \pm 6 \mathrm{~cm}$ (height). Tussocks accounted for $18 \%$ of plot area, i.e., center occupied $2.3 \mathrm{~m}^{2}$; edge $8.3 \mathrm{~m}^{2}$; and flat $49.4 \mathrm{~m}^{2}$ (Table 1). Since $R$. alba had less than $0.1 \%$ cover in all the plots, the effects of 
R. alba on other plant species was least.

During September 2005 and September 2006, 18 vascular plant taxa consisting of 4658 individuals were marked (Table 1). In the plots, 17 species with 1903 individuals were found at the edge, 27 individuals consisting of 5 species in the center, and 2728 individuals of 16 species in flat areas. At the edge, $H$. radicata accounted for $50 \%$ of total individuals, S. virgaurea $13 \%$ and $D$. rotundifolia $10 \%$. In the flat, $H$. radicata accounted for $32 \%$ of total individuals, $D$. rotundifolia $17 \%$ and $M$. japonica $16 \%$. Three dominant species, H. radicata, S. virgaurea and L. sessilifolia, accounted for $70 \%$ of individuals at the edge and center, and $59 \%$ in all the plots. Fertile individuals accounted for less than $4 \%$ of each species, except for $39 \%$ in the case of $D$. rotundifolia. Peat excavations confirmed that most aboveground shoots were distinct individuals, although all species can reproduce vegetatively.

At the center, D. rotundifolia, M. japonica and S. virgaurea were not distributed (Table 2), and $H$. radicata and $L$. sessilifolia were not over 10 individuals. At seedling and juvenile stages, for the five species except the seedling stage of L. sessilifolia, individuals were distributed more at the edge than in the flat.

The effects of tussock-forming species on establishment were different between the common species. $H$. radicata and $S$. virgaurea were distributed more in E. vaginatum tussock edge than in $C$. middendorffii edge, and $M$. japonica was distributed more in $C$. middendorffii edge. On fertile stage, $D$. rotundifolia individuals were distributed more at the edge, and nearly all $H$. radicata individuals were distributed at the edge. Most flowering individuals of $L$. sessilifolia and S. virgaurea were distributed at the edge, although the flowering rate was low. In total, therefore, more individuals established at the edge throughout the growth stages for all the common species.

Survival, growth and flowering

More than $70 \%$ of individuals of D. rotundifolia, L. sessilifolia, M. japonica and S. virgaurea 
survived from September 2005 to May 2006, while only $20 \%$ of $H$. radicata individuals survived (Table 2). For $H$. radicata, survival rates increased at the edge with increasing plant size, indicating that larger individuals had greater overwintering abilities. While, the edge did not affect the survival of all examined natives. Most overwintered individuals survived to September 2006 for all the species, except that the mortality of $S$. virgaurea was constant throughout the surveyed period. Plant size on S. virgaurea was positively related to survival during snow-free period.

Plant size in 2006 was positively related to plant size in the previous year for all the species (Table 2). On growth, the edge positively affected $H$. radicata, L. sessilifolia and $S$. virgaurea, while microhabitat did not influence D. rotundifolia and M. japonica. The effects of tussocks on the growth of $H$. radicata and $L$. sessilifolia did not differ between the two tussock-forming species. The growth of $S$. virgaurea was higher in $C$. middendorffii tussock edge than in the flat. While, the growth was not significantly different between $E$. vaginatum tussock edge and flat. Larger individuals produced flowers on D. rotundifolia and L. sessilifolia, and were not significantly different between edge and flat (Table 2). For H. radicata and S. virgaurea, most fertile individuals established at the edge. Only five individuals attained fertile stage for $M$. japonica.

Seed immigration and seedling emergence

Seed traps captured 3162 seeds, consisting of 12 species, from June to October 2006, and 10 of these species produced wind-dispersed seeds (Table 1). Seed dispersal mostly occurred in summer and fall for the common species (Fig. 2a). The seeds of two tussock-forming species, C. middendorffii and E. vaginatum, were trapped frequently. Except these two tussock-forming species, the most abundant species of seeds observed was $R$. alba, with 1008 seeds. The total number of seeds, for the five examined species, accounted for $34 \%$ of seeds. The four natives dispersed seeds for a short period, between late September and late October (Fig. 2a). The 
seedling emergence of these four species started before seed dispersal began, indicating that these four species formed a seedbank. Seed-dispersal duration of the exotic, H. radicata was longer, from late July to late October, and overlapped with the timing of seedling emergence, so that both seeds from immigration and seedbank could contribute the seedling emergence.

Model 1 was selected for the seed dispersal of M. japonica and S. virgaurea (Fig. 2b), showing that the seeds dispersed evenly. Model 3 was selected for D. rotundifolia, H. radicata and L. sessilifolia, and meant that seed densities differed between three microhabitats. However, the difference was not statistically significant on $L$. sessilifolia. Seed immigration was significantly higher in the flat than in the center and the edge for $H$. radicata. Seeds immigrated more to the edge for $D$. rotundifolia. Except $D$. rotundifolia that had short flowering stalks less than $13 \mathrm{~cm}$, flowering stalks exceeded tussock height, i.e., the maximum flowering stalk heights on $H$. radicata, L. sessilifolia, M. japonica and S. virgaurea were 54, 38, 71 and $47 \mathrm{~cm}$, respectively.

Environments on tussocks and neighboring areas

Groundwater level gradually decreased from $-10.2 \pm 2.5 \mathrm{~cm}$ (mean $\pm \mathrm{SD}$ ) in late April to $-21.9 \pm$ $4.4 \mathrm{~cm}$ in July 2006 in all the plots, and then increased to $-10.6 \pm 2.3 \mathrm{~cm}$ until October. In particular, groundwater level was lowest in July. Groundwater was never above the ground surface during snow-free periods, unless heavy rain occurred.

PAR was higher in flat areas throughout the snow-free period (Fig. 3). At the center, PAR was the lowest of the three microhabitats, except for early spring, and decreased with time due to shading by leaf flushing. The tussock center on E. vaginatum tussocks was lower than that on C. middendorffii in May, probably because E. vaginatum shoots emerged earlier than $C$. middendorffii. PAR seasonally changed little at edges covered constantly with litter.

Mean peat temperature was higher in the flat than in the center and edge from late spring to late summer (Fig. 3). After summer, the differences between the microhabitats became 
narrower. Mean daily maximum temperature in peat was $25.3^{\circ} \mathrm{C}$ in flat areas and $23.5^{\circ} \mathrm{C}$ in the center in August, and the minimum was $9.7^{\circ} \mathrm{C}$ in flat areas and $6.9^{\circ} \mathrm{C}$ at the center in May. Daily temperature fluctuation ranged from $0.6^{\circ} \mathrm{C}$ to $8.5^{\circ} \mathrm{C}$ at the center, and became larger in the flat, from $1.6^{\circ} \mathrm{C}$ to $22.6^{\circ} \mathrm{C}$. Temperature at the edge showed an intermediate range between the center and flat areas. Temperatures were not different between $C$. middendorffii and $E$. vaginatum tussocks.

Water content in peat, which was different between microhabitats $(P<0.001)$ but not between tussock-forming species, changed seasonally $(P<0.001)$ and decreased particularly from June to July (Fig. 3). Tussock centers were driest with less than 57\% water content throughout the surveyed period. Water content fluctuated monthly from $65 \pm 8 \%$ (mean \pm SD) to $74 \pm 7 \%$ at $0 \mathrm{~cm}$ from the base of tussocks and from $74 \pm 8 \%$ to $82 \pm 6 \%$ at $10 \mathrm{~cm}$, and more than $77 \pm 6 \%$ at $20-80 \mathrm{~cm}$. These results showed that water content was lower at the edge than in the flat.

\section{Discussion}

Effects of tussocks on plant distribution patterns

Tussock edge facilitated plant colonization by various ways in the post-mined peatland, while the center inhibited it. Tussock centers often provide safe sites for plant establishment in natural wetlands, such as an alpine peatland in China (Tsuyuzaki and Tsujii 1992), a northern Californian riparian wetland, USA (Levine 2000), and a beaver-inhabited wetland in Mississippi, USA (Ervin 2005). The differences of plant distribution patterns between the post-mined and un-mined natural wetlands are derived from peat moisture and water level. In the latter three natural wetlands, tussock edge is inundated throughout the plant-growing season and thus inhibits the plant establishment, but the tussock protects plants established on the center from flooding (Levine 2000) and continuous waterlogging (Fogel et al. 2004). After the development of 
peat-covered ground surface on the post-mined Sarobetsu mire, the surface is not covered with groundwater even soon after snow-melt. Therefore, plant establishment in the three microhabitats is not limited by inundation, indicating that stresses in post-mined peatland are different from these in natural wetlands.

Plant establishment patterns throughout life history

\section{Seed immigration}

Diverse microtopography provided by tussocks traps seeds effectively; for example, seeds are captured by Spartina alterniflora-created microtopography on a cobble beach (Bruno 2000), and raised Carex stricta tussocks on tidal freshwater marshes (Crain and Bertness 2005). All the common species produce minute seeds, and three of them develop wind-dispersed seeds, i.e., $H$. radicata and $S$. virgaurea produce seeds with pappus and D. rotundifolia has winged seeds. On wind-dispersed species, taller flower stalks increase the distance of seed dispersal (Soons and Heil 2002; Soons 2006). The seeds of D. rotundifolia producing the shortest flower stalks and were captured more at the edge, where flowering individuals establish well. In contrast, the seeds of $H$. radicata, producing the tallest flower stalks, were caught more on the flat, and the seeds of the other three species, of which flower stalks were taller than tussocks, were captured evenly by the three microhabitats. The height of flower stalks is likely to be related to seed dispersal patterns, and thus the seed-trap effects of tussocks were weak for most common species. However, most seeds of natives germinated at the edge in the next year, suggesting that the seeds were transferred by secondary seed dispersal, e.g., by water, soon after snow-melt.

\section{Seedling emergence}

No seedlings established at the tussock center. Substrates made of shoot and litter affect seed 
germination (Xiong and Nilsson 1999). Water content seemed to be insufficient for seed germination for most wetland plants at the center, in particular, from June to July when seed germination peaked.

More seedlings emerged at the edge than in the flat for all examined species except $L$. sessilifolia. The thin peat surface in the flat was considered to be too dry for seed germination, although water content at $0-12 \mathrm{~cm}$ depth was higher in the flat than in the edge. In fact, cracks occurred on the ground surface in the flat during summer, suggesting that the thin surface layer in the flat suffered from drought. In addition, wind erosion occurs more in the flat (Campbell et al. 2002). While, the edge improved water content and reduced wind erosion, and has advantages for seed germination (Campbell et al. 2002; Eckstein and Donath 2005).

\section{Survival}

Stress is one of the major causes of high mortality, and is divided into two seasons for wetland plants in cool temperate climate regions, i.e., summer and winter. In the summer season, strong solar radiation, drought and temperature fluctuation increase mortality (Price 1997; Campbell and Rochefort 2003). In the winter season from late fall to early spring, frost and ground surface movements by melting-snow induce high mortality (Campbell and Rochefort 2003). In Sarobetsu post-mined peatland, the survival declined from fall to the next spring for most species, showing that winter stress was the prime determinant on plant survival.

The survival of $H$. radicata is higher in edges covered with tussock litter, decreasing frost damage (Groeneveld and Rochefort 2005). An exotic species, H. radicata, showed different seed dispersal timing and seed-dispersal period from the natives. The seed germination of $H$. radicata occurs from summer to fall, while native species germinate before July. Therefore, $H$. radicata seedlings had a shorter growth period before overwintering. The edge supported high seedling survival for $H$. radicata, and facilitated the establishment of this exotic species. The survival of native species is not influenced by the presence of tussocks, probably because natives 
are tolerant more to frost and/or low temperature (Crowder et al. 1990; Taylor et al. 2001).

\section{Growth and flowering}

The annual growth of $H$. radicata, L. sessilifolia and S. virgaurea was higher at the edge than in the flat, while the growth of S. virgaurea was not facilitated by the edge of E. vaginatum. Tussocks create safe sites for seedling survival and growth by providing stable ground surface in cobbled beach and in coastal marsh (Bruno 2000; Egerova et al. 2003). In contrast, tussocks do not facilitate plant growth in freshwater marsh, because of competition between tussock-forming species and established species (Ervin and Wetzel 2002). In the case of Sarobetsu mire, tussock edge is a safe site for growth via declining direct solar radiation and increasing stability of ground surface by tussock litter. The annual growth of $D$. rotundifolia and $M$. japonica did not differ between the edge and the flat, suggesting that differences of light conditions did not influence growth. Fertile individuals established more at the edge, probably because tussocks indirectly promote flowering, via higher survival and faster growth, in particular, for $D$. rotundifolia. Thereafter, the distributional patterns of juvenile and fertile individuals are reflected by the distribution of seedlings. The dependence on the edge becomes higher with progressing life-history stages for $H$. radicata, $L$. sessilifolia and $S$. virgaurea. In contrast to the edge, the center inhibits plant establishment. Since the area of the center is $1 / 4$ of that of the edge, the aggregative effects of tussocks are facilitative to the most common species.

Functions of tussocks on revegetation

On sedge meadows in southern Wisconsin, USA, Carex stricta tussocks support a diversity of cohabitant species, and the cohabitant composition varies between tussock microhabitats depending on litter cover and water level (Peach and Zedler 2006). In Sarobetsu mire, tussock edge facilitates the establishment of common species, in particular, $H$. radicata, showing that the 
diverse microenvironments created by tussocks with litter allow the establishment of exotic species. Light intensity in early spring is higher on $C$. middendorffii tussocks than on $E$. vaginatum tussocks, probably due to differences in shoot phenology. The results of model selection supported that the two tussock-forming species affected differently plant establishment via different life-history stages. To clarify this, we require more fine-scaled monitoring of the shoot phenology of tussocks.

The age of tussocks was less than 25 years, even if tussocks established soon after the formation of the ground surface, and a few tussocks outside the plots began to collapse and were occupied by mosses probably due to tussock ageing. Facilitation on each tussock seems to be short due to the lifespan. However, various-sized tussocks were distributed in the post-mined peatland, suggesting that facilitation by tussocks persists for a long time at the landscape level. The revegetation of Sphagnum spp. was restricted in the study sites, because of low groundwater level in summer (Nishimura et al. 2009). While, exotic species represented by $H$. radicata utilized tussock edges well, implying that tussocks facilitate the plant establishment but may modify successional sere. The development of tussocks plays an important role in revegetation, even on post-mined peatlands.

\section{Acknowledgements}

We are grateful to Titus $\mathrm{JH}$ and Ward $\mathrm{R}$ for their critical readings of the manuscript. We thank Kubo T for statistical analysis, Akasaka M and Ida TY for advice, and Nishimura A and Egawa C for support in field survey. We also thank all members in the laboratory of Regional Ecosystems, GSEES, Hokkaido University. Cordial thanks are also due to the staff members of the Ministry of Environment of Japan and Toyotomi Town Office for permission and support to carry out this study. This works is partly supported by Japan Society for the Promotion of Science. 


\section{References}

Badano EI, Villarroel E, Bustamante RO, Marquet PA, Cavieres LA (2007) Ecosystem engineering facilitates invasions by exotic plants in high-Andean ecosystems. J Ecol 95:682-688

Bergelson J (1990) Life after death: Site pre-emption by the remains of Poa Аnпиa. Ecology 71:2157-2165

Bertness MD, Callaway R (1994) Positive interactions in communities. Trends Ecol Evol 9:191-193

Bosy JL, Reader RJ (1995) Mechanisms underlying the suppression of forb seedling emergence by grass (Poa Pratensis) litter. Funct Ecol 9:635-639

Burnham KP, Anderson DR (2002) Model selection and multimodel inference: a practical information-theoretic approach, 2nd edn. Springer-Verlag, New York, NY, USA

Bruno JF (2000) Facilitation of cobble beach plant communities through habitat modification by Spartina alterniflora. Ecology 81:1179-1192

Callaway RM, Walker LR (1997) Competition and facilitation: A synthetic approach to interactions in plant communities. Ecology 78:1958-1965

Campbell DR, Lavoie C, Rochefort L (2002) Wind erosion and surface stability in abandoned milled peatlands. Can J Soil Sci 82:85-95

Campbell DR, Rochefort L (2003) Germination and seedling growth of bog plants in relation to the recolonization of milled peatlands. Plant Ecol 169:71-84

Cavieres LA, Quiroz CL, Molina-Montenegro MA (2008) Facilitation of the non-native Taraxacum officinale by native nurse cushion species in the high Andes of central Chile: are there differences between nurses? Funct Ecol 22:148-156

Chabrerie O, Alard D (2005) Comparison of three seed trap types in a chalk grassland: toward a standardised protocol. Plant Ecol 176:101-112

Chapin FS, Walker LR, Fastie CL, Sharman LC (1994) Mechanisms of primary succession 
following deglaciation at Glacier Bay, Alaska. Ecol Monogr 64:149-175

Crain CM, Bertness MD (2005) Community impacts of a tussock sedge: Is ecosystem engineering important in benign habitats? Ecology 86:2695-2704

Crooks JA (2002) Characterizing ecosystem-level consequences of biological invasions: the role of ecosystem engineers. Oikos 97:153-166

Crowder AA, Pearson MC, Grubb PJ, Langlois PH (1990) Drosera L. J Ecol 78:233-267

Eckstein RL, Donath TW (2005) Interactions between litter and water availability affect seedling emergence in four familial pairs of floodplain species. J Ecol 93:807-816

Egawa C, Koyama A, Tsuyuzaki S (in press) Relationships between the developments of seedbank, standing vegetation and litter in a post-mined peatland. Plant Ecol doi: $10.1007 / \mathrm{s} 11258-008-9536-5$

Egerova J, Proffitt CE, Travis SE (2003) Facilitation of survival and growth of Baccharis halimifolia L. by Spartina alterniflora Loisel. in a created Louisiana salt marsh. Wetlands $23: 250-256$

Ervin GN (2005) Spatio-temporally variable effects of a dominant macrophyte on vascular plant neighbors. Wetlands 25:317-325

Ervin GN, Wetzel RG (2002) Influence of a dominant macrophyte, Juncus effusus, on wetland plant species richness, diversity, and community composition. Oecologia 130:626-636

Facelli JM, Pickett STA (1991) Plant litter: Light interception and effects on an old-field plant community. Ecology 72:1024-1031

Fogel BN, Crain CM, Bertness MD (2004) Community level engineering effects of Triglochin maritima (seaside arrowgrass) in a salt marsh in northern New England, USA. J Ecol 92:589-597

Groeneveld EVG, Rochefort L (2005) Polytrichum strictum as a solution to frost heaving in disturbed ecosystems: A case study with milled peatlands. Restor Ecol 13:74-82

Hotes S, Poschlod P, Takahashi H (2006) Effects of volcanic activity on mire development: case studies from Hokkaido, northern Japan. Holocene 16: 561-573 
Jefferson RG, Usher MB (1989) Seed rain dynamics in disused chalk quarries in the Yorkshire-Wolds, England, with special reference to nature conservation. Biol Conserv 47:123-136

Lavoie C, Marcoux K, Saint-Louis A, Price JS (2005) The dynamics of a cotton-grass (Eriophorum vaginatum L.) cover expansion in a vacuum-mined peatland, southern Quebec, Canada. Wetlands 25:64-75

Levine JM (2000) Complex interactions in a streamside plant community. Ecology $81: 3431-3444$

Morris WF, Wood DM (1989) The role of Lupine in succession on Mount St. Helens: facilitation or inhibition? Ecology 70:697-703

Nishimura A, Tsuyuzaki S, Haraguchi A (2009) A choronosequence approach for detecting revegetation patterns after Sphagnum-peat mining, northern Japan. Ecol Res 24:237-246

Paquet JM, Caron J, Banton O (1993) In-situ determination of the water desorption characteristics of peat substrates. Can J Soil Sci 73:329-339

Peach M, Zedler JB (2006) How tussocks structure sedge meadow vegetation. Wetlands 26:322-335

Pellerin S, Lavoie C (2000) Peatland fragments of southern Quebec: recent evolution of their vegetation structure. Can J Bot 78:255-265

Price J (1997) Soil moisture, water tension, and water table relationships in a managed cutover bog. J Hydrol 202: 21-32

Rousset O, Lepart J (2000) Positive and negative interactions at different life stages of a colonizing species (Quercus humilis). J Ecol 88:401-412

R Development Core Team 2007 R: A language and environment for statistical computing. R Foundation for Statistical Computing, Vienna, Austria

SDMO (Sapporo District Meteorological Observatory) (2006) http://www.sapporo-jma. go.jp/ Cited 28 May 2008

Soons MB (2006) Wind dispersal in freshwater wetlands: Knowledge for conservation and 
restoration. Appl Veg Sci 9:271-278

Soons MB, Heil GW (2002) Reduced colonization capacity in fragmented populations of wind-dispersed grassland forbs. J Ecol 90:1033-1043

Taylor K, Rowland AP, Jones HE (2001) Molinia caerulea (L.) Moench. J Ecol 89:126-144

Tuittila ES, Rita H, Vasander H, Laine J (2000) Vegetation patterns around Eriophorum vaginatum L. tussocks in a cut-away peatland in southern Finland. Can J Bot 78:47-58

Tsuyuzaki S, Tsujii T (1992) Size and shape of Carex meyeriana tussocks in an alpine wetland, northern Sichuan Province, China. Can J Bot 70:2310-2312

Walker LR, Clarkson BD, Silvester WB, Clarkson BR (2003) Colonization dynamics and facilitative impacts of a nitrogen-fixing shrub in primary succession. J Veg Sci 14:277-290

Xiong SJ, Nilsson C (1999) The effects of plant litter on vegetation: a meta-analysis. J Ecol 87:984-994

Yamada M, Takahashi H (2004) Frost damage to Hemerocallis esculenta in a mire: relationship between flower bud height and air temperature profile during calm, clear nights. Can J Bot $82: 409-419$ 


\section{Figure legends}

Fig. 1 Spatial distribution of tussocks and five common species in six $1 \times 10 \mathrm{~m}$ plots, A to $\mathrm{F}$, in a post-mined area on Sarobetsu mire, northern Japan, in August 2006. Two plots were established in each of three sparsely vegetated, tussock-dominated sites. Circles indicate the circumference of the tussock centers

Fig. 2 a: Seasonal fluctuations of seed dispersal and seedling emergence on common species from June to October 2006. Number of seedlings emerged in six $1 \times 10 \mathrm{~m}$ plots and number of seeds captured by 294 seed traps are shown. b: Number of seeds (mean \pm SE) captured by seed traps on three microhabitats (center, edge and flat). Mean number of seed traps is shown in parentheses. The best clusters determined by AIC model selection are shown by angled brackets and model codes 1-3. Each numeral above bracket indicates the coefficient of difference in number of seeds from flat to other microhabitat(s), confirmed by GLM when models 2 and 3 are adapted. $* * P<0.01, * P<0.05,{ }^{\text {ns }} P>0.05$

Fig. 3 Monthly fluctuations (mean \pm SD) of microenvironments on three microhabitats (center, edge and flat). At the center and edge, microenvironments were measured on Carex middendorffii and Eriophorum vaginatum tussock, respectively. a: Daily cumulative photosyntheticaly active radiation (PAR) on ground surface from May to September 2007, though the logger of PAR on edge of $C$. middendorffii tussock failed to record. b: Daily mean temperature at $5 \mathrm{~cm}$ below the ground surface calculated by 1-hour interval measurements from June to September in 2006. At the edge, thermometers were set up at the east and west sides of tussocks. $\quad$ c: Range of temperature within a day (maximum minus minimum temperature). d: Monthly changes in water content from May to September in 2006 along 22 tussocks at east and west sides. For flat areas, PAR (a) and temperatures $(\mathbf{b}, \mathbf{c})$ were measured at 80 -cm east from edge of E. vaginatum tussock, and water content (d) was measured on 11 C. middendorffii and 11 
E. vaginatum tussocks 
Table 1 Total number of individuals with reference to three microhabitats (center, edge and flat) on six $1 \times 10 \mathrm{~m}$ plots established in post-mined peatland, Sarobetsu mire, from September 2005 to September 2006. Asterisks indicate that seed traps captured the seeds. The area of each microhabitat is shown in parentheses

\begin{tabular}{|c|c|c|c|c|c|}
\hline Species & Seed dispersal & $\begin{array}{l}\text { Center } \\
\left(2.3 \mathrm{~m}^{2}\right) \\
\end{array}$ & $\begin{array}{c}\text { Edge } \\
\left(8.3 \mathrm{~m}^{2}\right)\end{array}$ & $\begin{array}{c}\text { Flat } \\
\left(49.4 \mathrm{~m}^{2}\right)\end{array}$ & $\begin{array}{c}\text { Total } \\
\left(60.0 \mathrm{~m}^{2}\right)\end{array}$ \\
\hline Hypochaeris radicata $\mathrm{L}$. & Wind* & 5 & 871 & 542 & 1418 \\
\hline Drosera rotundifolia $\mathrm{L}$. & Wind* & 0 & 174 & 278 & 452 \\
\hline Solidago virgaurea $\mathrm{L}$. var. leiocarpa Benth. & Wind* & 6 & 221 & 175 & 402 \\
\hline Moliniopsis japonica Hayata & Wind* & 0 & 99 & 270 & 369 \\
\hline Carex middendorffii Fr. Schm. & Gravity* & 0 & 66 & 163 & 229 \\
\hline Lobelia sessilifolia Lamb. & Gravity/Wind* & 13 & 134 & 80 & 227 \\
\hline Eriophorum vaginatum L. & Wind* & 0 & 70 & 78 & 148 \\
\hline Hydrangea paniculata Sieb. & Gravity & 0 & 78 & 23 & 101 \\
\hline Sanguisorba tenuifolia Fisch. ex Link var. alba Trautv. et Mey & Wind & 1 & 21 & 41 & 63 \\
\hline Calamagrostis epigeios Roth & Wind & 0 & 3 & 13 & 16 \\
\hline Spiranthes sinensis Ames var. amoena Hata & Gravity & 2 & 8 & 4 & 14 \\
\hline Iris laevigata Fisch. & Gravity & 0 & 1 & 2 & 3 \\
\hline Gentiana trifolia Pall. var. japonica Hata & Wind & 0 & 1 & 1 & 2 \\
\hline Rubus chamaemorus $\mathrm{L}$. & Animal & 0 & 0 & 2 & 2 \\
\hline Betula maximowicziana Regel & Wind & 0 & 1 & 0 & 1 \\
\hline Hosta rectifolia Nakai & Wind* & 0 & 1 & 0 & 1 \\
\hline Vaccinium oxyсосcus L. & Animal & 0 & 0 & 1 & 1 \\
\hline Unknown spp. & - & 0 & 4 & 3 & 7 \\
\hline Total & & 27 & 1753 & 1676 & 3456 \\
\hline Rhynchospora alba Vahl $^{\text {a) }}$ & Gravity* & 0 & 150 & 1052 & 1202 \\
\hline
\end{tabular}

a) The individuals of $R$. alba were not counted when the turfs were developed. $R$. alba turf cover was less than $0.1 \%$ in total, $0.02 \mathrm{~m}^{2}$ at the edge; $0.07 \mathrm{~m}^{2}$ on the flat, and zero at the center. Note: The total number of individuals on Phragmites australis W. Clayton, of which seeds were captured by seed traps, was 223 and most of them were established in the flat, although the microhabitats were not recorded. 
Table 2 Estimated effects of microhabitat on distribution, survival, growth and flowering for common species. Number of individuals on each microhabitat in 2006 was compared by GLM on three growth stages, seedling, juvenile and fertile. Survivals in winter and in summer and flowering in 2006 were investigated by GLMM, and annual growth was by GLM. Effects of plant size in the prior year were also investigated. Significant differences are compared between flat and edge, and between flat and center. Numerals in density show number of common species per square meter, those in survival and flowering were by rates, those in growth were by plant size in 2006 minus in 2005. C. middendorffii and E. vaginatum are species forming tussock microhabitats. Sample size was shown in parentheses. $\quad * * * P<0.001, * * P<0.01, * P<0.05,{ }^{\text {ns }} P>0.05$. ' '-' not determined, due to sample size

\begin{tabular}{|c|c|c|c|c|c|c|c|c|c|c|c|c|c|c|c|}
\hline \multirow[b]{3}{*}{ Species } & \multirow[b]{3}{*}{ Variables } & \multicolumn{6}{|c|}{ Density } & \multicolumn{8}{|c|}{ Life history } \\
\hline & & \multicolumn{2}{|c|}{ Seedling } & \multicolumn{2}{|c|}{ Juvenile } & \multicolumn{2}{|c|}{ Fertile } & \multicolumn{2}{|c|}{ Survival (Winter) } & \multicolumn{2}{|c|}{ Survival (Summer) } & \multicolumn{2}{|l|}{ Growth } & \multicolumn{2}{|c|}{ Flowering } \\
\hline & & $\left(\mathrm{m}^{-2}\right)$ & $z$ value & $\left(\mathrm{m}^{-2}\right)$ & $z$ value & $\left(\mathrm{m}^{-2}\right)$ & $z$ value & $(\%)$ & $z$ value & $(\%)$ & $z$ value & $\left(\mathrm{cm}^{2}\right)$ & $z$ value & $(\%)$ & $z$ value \\
\hline \multirow{5}{*}{ Drosera rotundifolia } & Plant size & & & & & & & & $0.89^{\mathrm{ns}}$ & & $0.90^{\mathrm{ns}}$ & & $3.33^{* * * *}$ & & $4.55^{* * * *}$ \\
\hline & Center (C. middendorffii ) & ) $0.0(0)$ & - & $0.0(0)$ & - & \multirow{2}{*}{$0.0(0)$} & & \multirow{2}{*}{$-(0)$} & & \multirow{2}{*}{ - (0) } & 年 & $-(0)$ & - & \multirow{2}{*}{$-(0)$} & \multirow{2}{*}{ - } \\
\hline & Center (E. vaginatum) & $0.0(0)$ & - & $0.0(0)$ & - & & & & & & - & $-(0)$ & - & & \\
\hline & Edge (C. middendorffii) & $5.6(19)$ & $4.42^{* * * *}$ & $0.9(3)$ & - & $8.8(73)$ & $9.37^{* * * *}$ & $79.4(107)$ & $1.35^{\mathrm{ns}}$ & \multirow{2}{*}{$96.1(152)$} & $-0.70^{\mathrm{ns}}$ & $16.2 \pm 27.3(27)$ & $-1.28^{\mathrm{ns}}$ & $83.1(83)$ & $0.68^{\mathrm{ns}}$ \\
\hline & $\begin{array}{l}\text { Edge (E. vaginatum) } \\
\text { Flat }\end{array}$ & $\begin{array}{l}8.9(44) \\
1.8(90)\end{array}$ & $\begin{array}{l}8.64 * * * \\
5.70\end{array}$ & $\begin{array}{l}2.6(13) \\
0.6(32)\end{array}$ & $\begin{array}{l}4.27 * * * \\
-2.45\end{array}$ & $2.1(103)$ & 7.46 & $71.4(185)$ & 4.17 & & 7.49 & $\begin{array}{r}30.3 \pm 35.9(56) \\
28.0 \pm 34.0(129)\end{array}$ & $\begin{array}{l}0.66^{15} \\
28.08\end{array}$ & $77.7(130)$ & -0.80 \\
\hline \multirow{6}{*}{ Hypochaeris radicata } & Plant size & & & & & & & & $6.47 * * *$ & & $2.09 *$ & \multirow{3}{*}{$-20.4(1)$} & $8.08 * * *$ & & \\
\hline & Center (C. middendorffii) & ) $0.0(0)$ & - & $0.0(0)$ & - & \multirow{2}{*}{$0.4(1)$} & & $-(0)$ & - & $-(0)$ & - & & 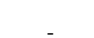 & $500(2)$ & \\
\hline & Center (E. vaginatum) & $0.0(0)$ & - & $0.8(1)$ & - & & & $25.0(4)$ & - & $100.0(2)$ & - & & & & \\
\hline & Edge (C. middendorffii $)$ & $4.4(15)$ & $1.56^{\mathrm{ns}}$ & $6.1(21)$ & $8.32^{* * * *}$ & & & $47.2(53)$ & $5.68^{* * *}$ & $96.7(30)$ & $1.45^{\mathrm{ns}}$ & & & & \\
\hline & Edge (E. vaginatum) & $28.8(142)$ & $19.42^{* * * *}$ & $26.6(131)$ & $18.38 * *$ & $4.7(39)$ & & $25.0(660)$ & $5.16^{* * *}$ & $85.8(212)$ & $0.67^{\mathrm{ns}}$ & $25.2 \pm 85.9(164)$ & $2.86^{* *}$ & $21.8(165)$ & - \\
\hline & Flat & $2.9(142)$ & 12.59 & $0.5(27)$ & -3.14 & $0.0(0)$ & & $6.8(400)$ & -13.27 & $77.6(67)$ & 4.11 & $11.7 \pm 26.1(16)$ & 8.43 & $0.0(16)$ & ـ \\
\hline & Plant size & & & & & & & & $0.01^{1 \mathrm{~ns}}$ & & $1.66^{\mathrm{ns}}$ & & $8.78^{* * * *}$ & & $2.50^{*}$ \\
\hline & $\begin{array}{l}\text { Center }(\text { C. middendorffii }) \\
\text { Center }(\text { E. vaginatum })\end{array}$ & $0.0(0)$ & - & $3.9(9)$ & - & $0.4(1)$ & - & $75.0(12)$ & $-0.17^{\mathrm{ns}}$ & $100.0(10)$ & - & $8.4 \pm 35.4(9)$ & - & $10.0(10)$ & - \\
\hline Lobel & $\begin{array}{l}\text { Edge (C. middendorffii }) \\
\text { Edge }(\text { E. vaginatum })\end{array}$ & $1.0(8)$ & - & $11.2(93)$ & $13.63 * * *$ & $0.7(6)$ & - & $77.1(118)$ & $0.74^{\mathrm{ss}}$ & $98.0(102)$ & $0.57^{\mathrm{ss}}$ & $6.0 \pm 19.5(87)$ & $3.83^{* * *}$ & $6.3(95)$ & $-0.05^{\text {ns }}$ \\
\hline & Flat & $0.1(4)$ & & $1.1(52)$ & 0.38 & $0.0(1)$ & & $69.3(75)$ & 2.78 & $94.7(57)$ & 1.82 & $5.2 \pm 12.8(51)$ & 14.15 & $1.9(52)$ & -2.18 \\
\hline & Plant size & & & & & & & & $0.97^{\mathrm{ns}}$ & & $0.66^{\mathrm{ns}}$ & & $6.92 * * *$ & & \\
\hline & $\begin{array}{l}\text { Center }(\text { C. middendorffii }) \\
\text { Center }(\text { E. vaginatum })\end{array}$ & $\begin{array}{l}0.0(0) \\
0.0(0)\end{array}$ & - & $\begin{array}{l}0.0(0) \\
0.0(0)\end{array}$ & - & $0.0(0)$ & - & $-(0)$ & & $-(0)$ & - & $-(0)$ & - & $-(0)$ & - \\
\hline Moliniopsis japonica & $\begin{array}{l}\text { Edge (C. middendorffii) } \\
\text { Edge (E. vaginatum) }\end{array}$ & $\begin{array}{l}5.3(18) \\
2.0(10)\end{array}$ & $\begin{array}{c}2.45^{*} \\
-1.04^{\mathrm{ns}}\end{array}$ & $\begin{array}{r}12.0(41) \\
2.6(13)\end{array}$ & $\begin{array}{c}10.34^{* * * *} \\
1.55^{\mathrm{ns}}\end{array}$ & $0.2(2)$ & - & $78.6(70)$ & $1.94^{\mathrm{ns}}$ & $89.3(84)$ & $1.58^{\mathrm{ns}}$ & $8(54)$ & $1.13^{\text {ns }}$ & $3.6(55)$ & - \\
\hline & Flat & $2.9(141)$ & 12.46 & $1.7(82)$ & 4.60 & $0.1(3)$ & & $65.4(127)$ & 1.26 & $80.9(220)$ & 3.35 & $0.2 \pm 1.3(76)$ & 2.20 & $3.8(78)$ & - \\
\hline & Plant size & & & & & & & & $1.27^{\mathrm{ns}}$ & & $2.37^{*}$ & & $5.55^{* * * *}$ & & \\
\hline & Center (C. middendorffii) & $0.0(0)$ & $\begin{array}{l}- \\
-\end{array}$ & $\begin{array}{l}0.0(0) \\
3.0(4)\end{array}$ & - & $0.0(0)$ & - & $66.7(6)$ & - & $50.0(4)$ & - & $\begin{array}{r}-(0) \\
-479+766(0)\end{array}$ & - & $0.0(2)$ & - \\
\hline Solidago virgaurea & $\begin{array}{l}\text { Center (E. vaginatum) } \\
\text { Edge (C. middendorffii })\end{array}$ & $\begin{array}{r}0.0(0) \\
4.7(16)\end{array}$ & $3.67^{\text {***** }}$ & $\begin{array}{r}3.0(4) \\
9.1(31)\end{array}$ & $8.56^{* * * *}$ & & & & & & & $104.5 \pm 126.0(25)$ & $5.96^{* * * *}$ & & \\
\hline & Edge $(E . v c$ & $15.8(78)$ & $14.15^{* * * *}$ & $12.6(62)$ & $12.48^{* * * *}$ & $1.0(13)$ & & 8. & 0.16 & 84) & $-1.33^{115}$ & $17.8 \pm 41.3(42)$ & $-0.76^{\mathrm{ns}}$ & 67) & - \\
\hline & Flat & $1.7(85)$ & 5.01 & $1.4(71)$ & 3.06 & $0.0(0)$ & & $78.9(90)$ & 1.43 & $72.0(150)$ & 2.57 & $18.7 \pm 33.4(59)$ & 2.32 & $0.0(59)$ & - \\
\hline
\end{tabular}


Fig. 1.

Fig. 1 (Koyama and Tsuyuzaki)

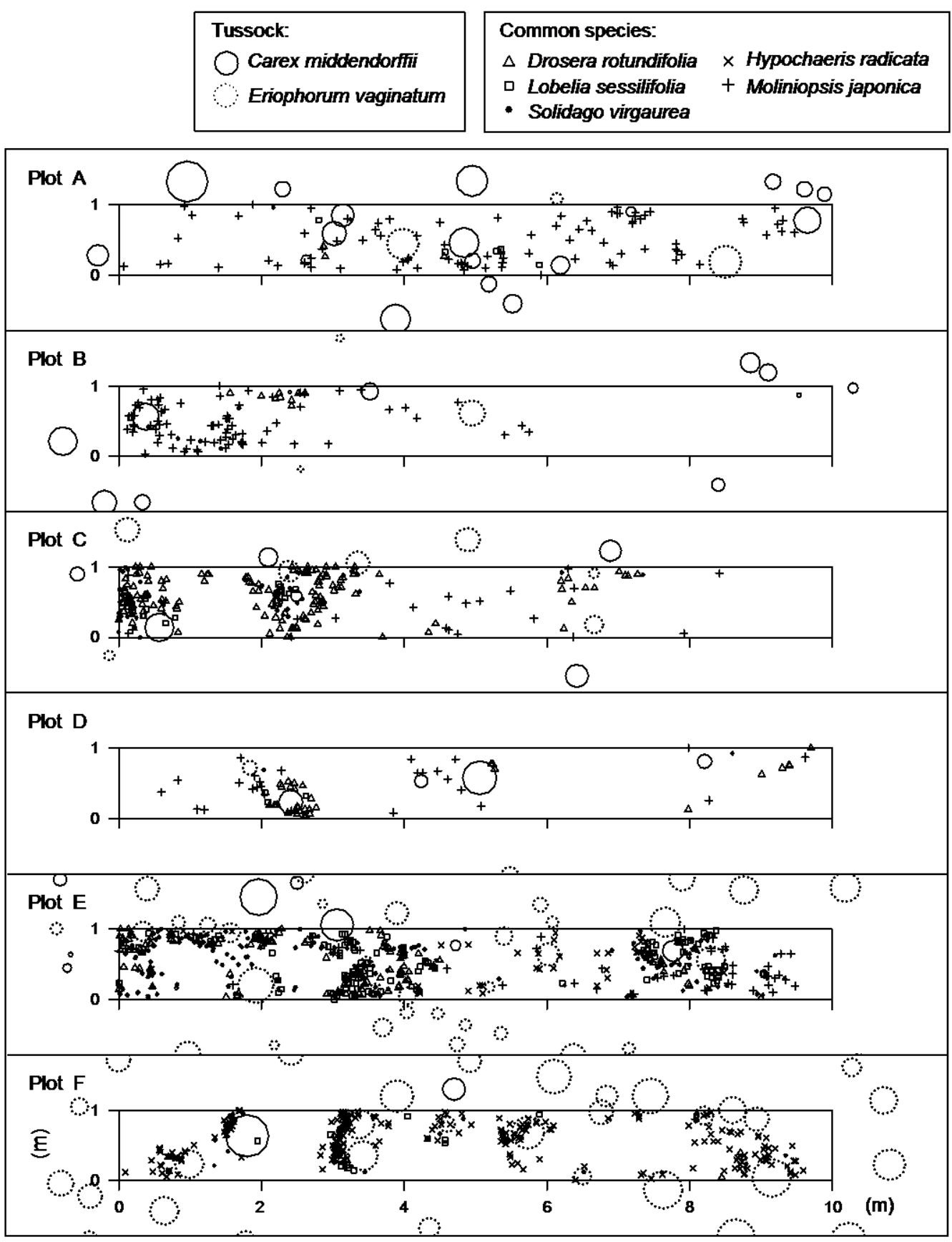


Fig. 2.

Fig. 2 (Koyama and Tsuyuzaki)

a Seed and seedling phenology

Drosera rotundifolia

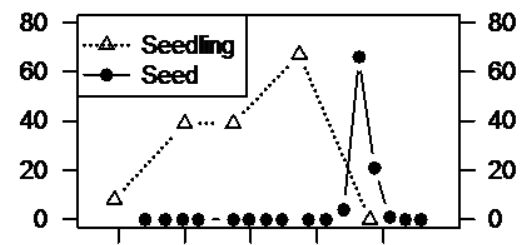

Hypochaeris radicata

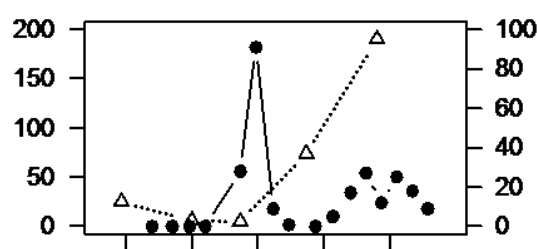

Lobelia sessilifolia

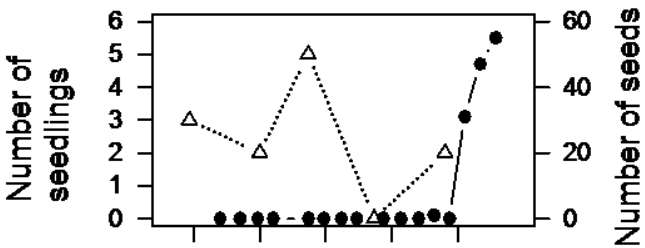

Moliniopsis japonica

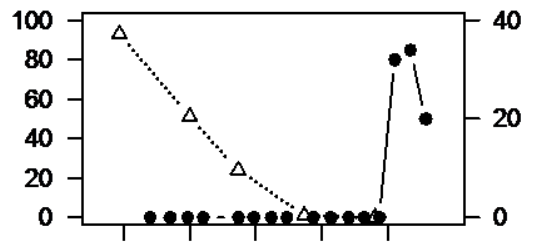

Solidago virgaurea

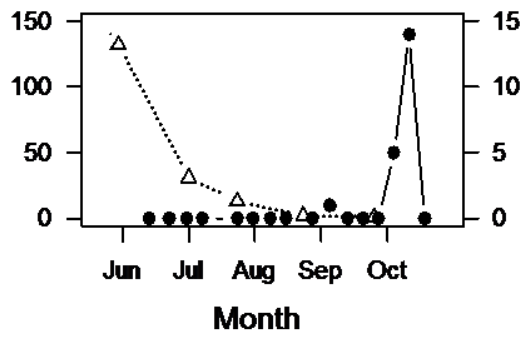

b Seed trap
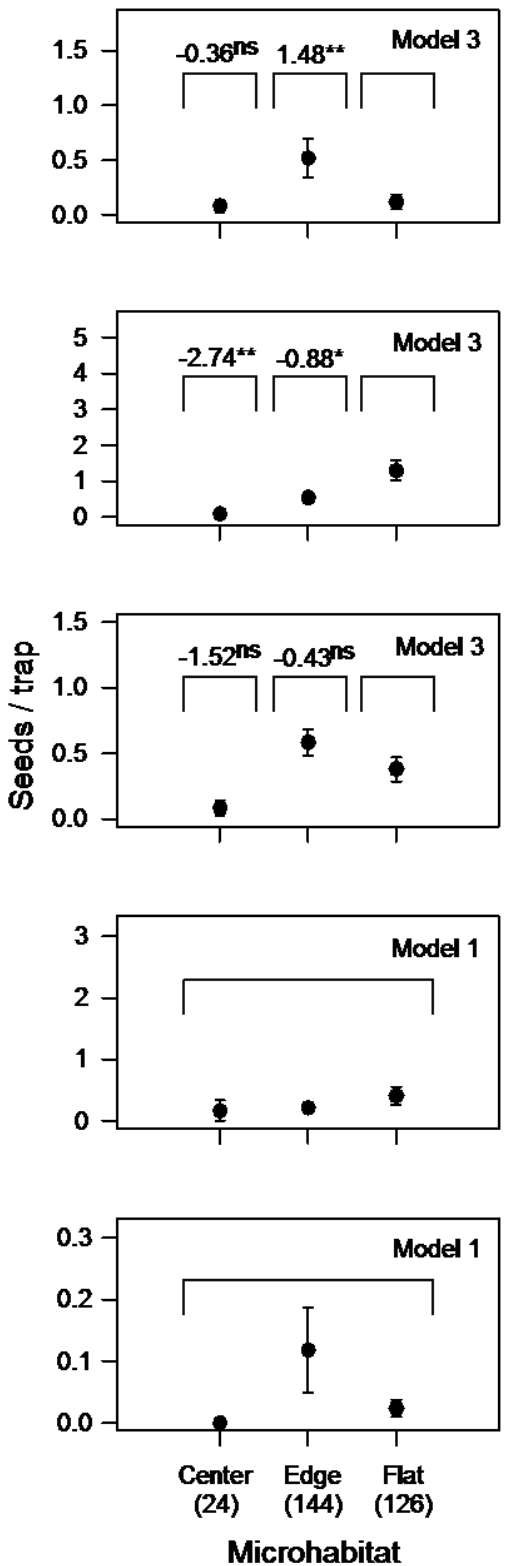
Fig. 3.

Fig. 3 (Koyama and Tsuyuzaki)

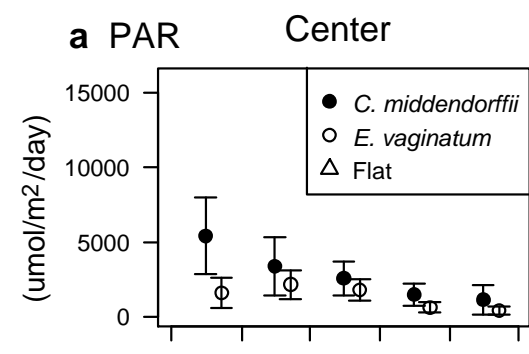

Edge

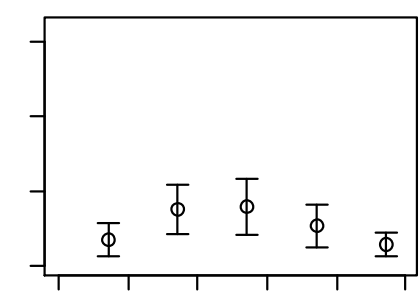

b Temperature

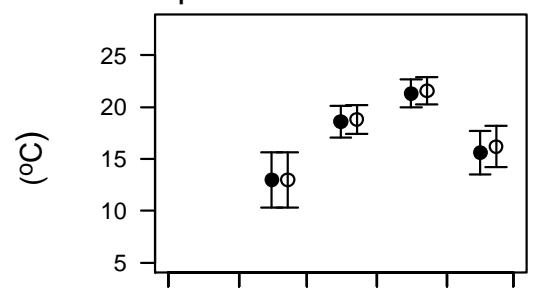

c Daily temperature range

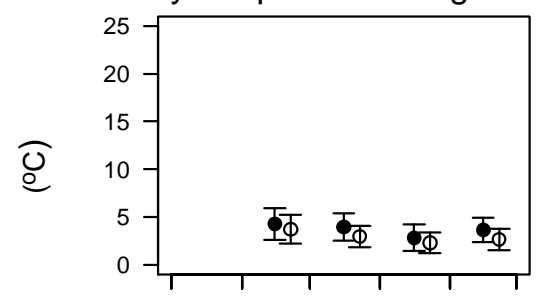

d Water content

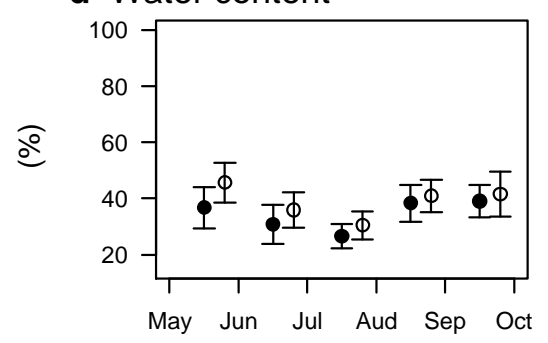

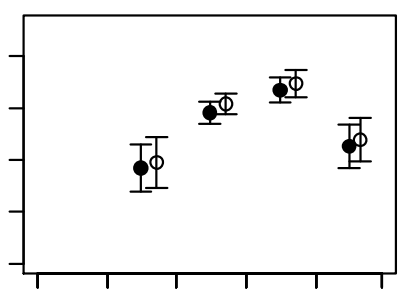
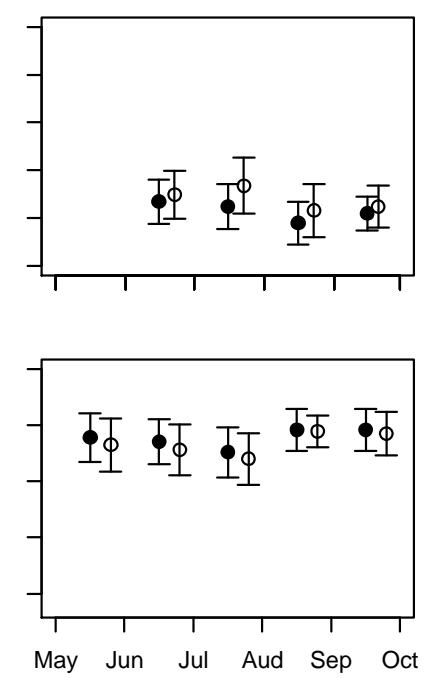
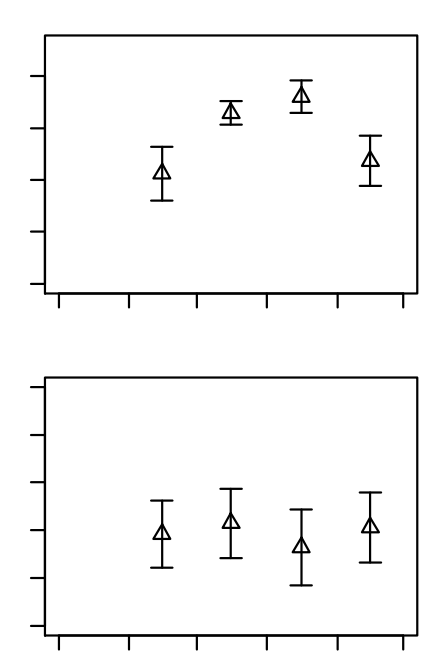

Flat
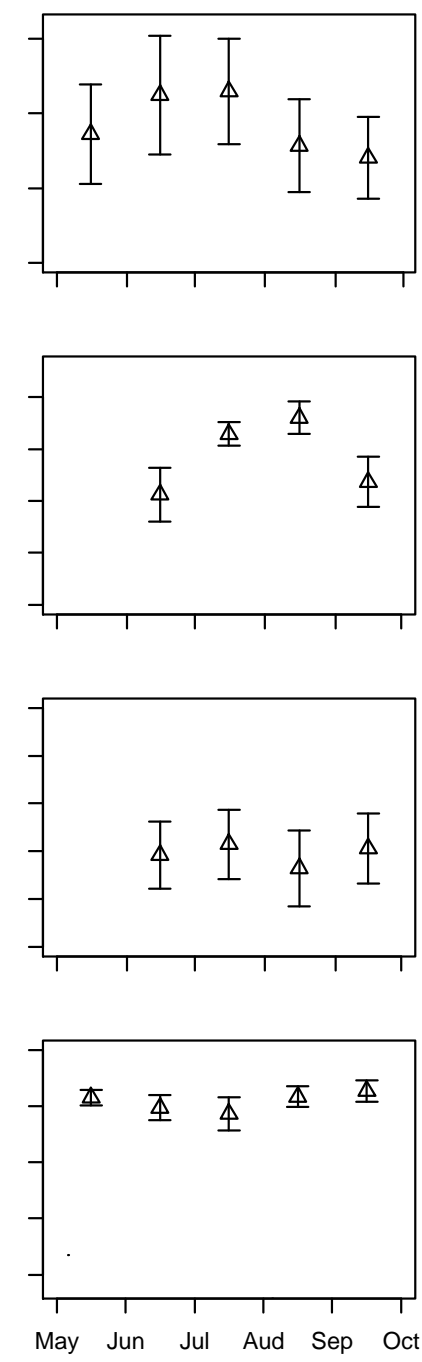